\title{
Maintenance and Degradation of Proteins in Intact and Severed Axons: Implications for the Mechanism of Long-Term Survival of Anucleate Crayfish Axons
}

\author{
Sandra L. Tanner, ${ }^{1}$ Elaine E. Storm, ${ }^{1}$ and George D. Bittner ${ }^{1,2,3}$ \\ 'Department of Zoology, ${ }^{2}$ College of Pharmacology, and ${ }^{3}$ Institute for Neurological Sciences Research, University of \\ Texas in Austin, Austin, Texas 78712
}

\begin{abstract}
Protein maintenance and degradation are examined in the severed distal (anucleate) portions of crayfish medial giant axons (MGAs), which remain viable for over 7 months following axotomy. On polyacrylamide gels, the silver-stained protein banding pattern of anucleate MGAs severed from their cell bodies for up to 4 months remains remarkably similar to that of intact MGAs. At 7 months postseverance, some (but not all) proteins are decreased in anucleate MGAs compared to intact MGAs. To determine the half-life of axonally transported proteins, we radiolabeled MGA cell bodies and monitored the degradation of newly synthesized transported proteins. Assuming exponential decay, proteins in the fast component of axonal transport have an average half-life of $14 \mathrm{~d}$ in anucleate MGAs and proteins in the slow component have an average half-life of $17 \mathrm{~d}$. Such half-lives are very unlikely to account for the ability of anucleate MGAs to survive for over 7 months after axotomy.

[Key words: axonal severance, axonal transport, axotomy, crayfish medial giant axon, protein degradation, protein turnover]
\end{abstract}

Since the nerve axon lacks polyribosomes (Peters et al., 1991), this cellular microdomain must depend on proteins synthesized in the cell body and conveyed by fast $(100-400 \mathrm{~mm} / \mathrm{d})$ and slow $(0.1-5 \mathrm{~mm} / \mathrm{d}$ ) axonal transport (reviewed in Grafstein and Forman, 1980; Brady and Lasek, 1982; Ochs, 1989). Vertebrate axons typically exhibit rapid (2-3 d) degeneration once severed from the trophic support provided by their cell bodies. In contrast, many invertebrate (and some lower vertebrate) axons remain morphologically intact and physiologically active for weeks to months after isolation from their cell bodies (reviewed in Bittner, 1981, 1988, 1991). Initially described for crayfish motor axons (Hoy et al., 1967), long-term survival (LTS) of anucleate axons (axonal segments severed from their cell bodies) has subsequently been shown in a variety of invertebrate nervous systems, including leech (Muller and Carbonetto, 1979), earthworms (Birse and Bittner, 1976), crickets (Clark, 1976), crustaceans (Bittner, 1973), and mollusks (Murphy and Kater,

\footnotetext{
Received May 16, 1994; revised July 5, 1994; accepted July 14, 1994.

This work was supported by an ATP grant to G.D.B. We especially thank Dr. Rebecca Sheller for her helpful advice during many phases of this research and for a careful reading of the final manuscript.

Correspondence should be addressed to Dr. George Bittner, Department of Zoology, University of Texas, Austin, TX 78712.

Copyright (C) 1995 Society for Neuroscience $0270-6474 / 95 / 150540-09 \$ 05.00 / 0$
}

1978). In fact, LTS of anucleate axons has also been reported in a number of vertebrates, such as goldfish (Zottoli et al., 1986; Blundon et al., 1990), garfish (Cancalon, 1983), frog (Matsumoto and Scalia, 1981), and a mutant strain of mice (Lunn et al., 1989).

The cellular mechanisms that enable an anucleate axon to remain viable following separation from the cell body are not yet understood. If the only source of axoplasmic proteins is via transport from the cell body, then it follows that all transported proteins that are critical to cytoplasmic survival of anucleate axons must exhibit unusually long half-lives. However, little is known about the metabolic degradation of transported proteins in intact axons, and measurements of protein turnover in anucleate axons exhibiting LTS have not yet been made.

In the present study, we examine whether long protein halflives (slow protein turnover) can account for the LTS of anucleate medial giant axons (MGAs) in the crayfish CNS. We have chosen the MGA because it is uniquely identifiable, very large (50-100 $\mu \mathrm{m}$ in diameter), and remains viable for over 7 months following axotomy (Wine, 1973; Bittner et al., 1974). In a recent study (Tanner, 1994; Tanner et al., 1994) we have shown that proteins synthesized in the MGA cell body are delivered to the axon via a fast $(\sim 62 \mathrm{~mm} / \mathrm{d})$ and a slow $(\sim 0.8 \mathrm{~mm} / \mathrm{d})$ transport component.

We now report that anucleate MGAs maintain the same protein profile as intact MGAs for up to 4 months; at 7 months postseverance some proteins decrease in anucleate MGAs. We find that the average half-life of radiolabeled protein in the fast component of axonal transport is $14 \mathrm{~d}$ and the average half-life of slow component protein is $17 \mathrm{~d}$ in anucleate MGAs. Furthermore, the half-life of slow component protein in anucleate axons does not differ significantly from that measured for intact axons (14 d). These half-lives are very unlikely to account for the morphological and functional integrity of anucleate MGAs for over 7 months.

\section{Materials and Methods}

Operative procedures in vivo. Freshwater crayfish (Procambarus clarkii), approximately $6 \mathrm{~cm}$ in body length, were purchased from Atchafalaya Biological Supply (Raceland, LA) and maintained in community holding tanks at $15-18^{\circ} \mathrm{C}$. The crayfish ventral nerve cord (VNC) consists of a series of bilaterally paired ganglia linked by interganglionic connectives. The VNC contains a pair of MGAs $(50-100 \mu \mathrm{m}$ in diameter) that originate from cell bodies in the supracsophagcal ganglion and terminate in the last abdominal ganglion. Although not myelinated, each MGA is surrounded by a sheath composed of alternating layers of glial cells and connective tissue.

Crayfish were immobilized ventral side up in a dissecting tray con- 
taining chilled physiological saline (Van Harreveld, 1936). A small flap of the ventral carapace overlying the supraesophageal ganglion was cut and retracted so that the ganglion and connectives were exposed. For most of the experiments, one of the connectives was cut at a site just caudal to the supraesophageal ganglion to produce an anucleate MGA and a contralateral intact MGA within the same preparation. In a few histological experiments, both MGAs were severed by cutting the entire VNC between the second and third abdominal ganglia. Crayfish were returned to holding tanks until sacrificed for histological or biochemical analyses.

Histology. Severed VNCs were excised and carefully pinned out to their original lengths on small strips of balsa wood. Tissues were fixed

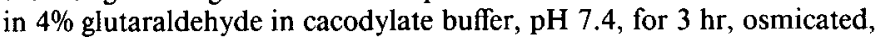
and processed into Spurr's plastic by standard procedures. Sections were obtained for light and electron microscopy as previously described (Ballinger and Bittner, 1980).

Protein analyses. VNCs from experimental animals severed for 1-7 months were dissected from crayfish, pinned down in a Sylgard petri dish, and covered with chilled saline. Equal lengths (beginning $\sim 1 \mathrm{~mm}$ from the cell body and extending $2.5 \mathrm{~cm}$ distally) of the anucleate MGA and the intact MGA from each VNC were carefully microdissected and homogenized directly in $17 \mu 1$ of sodium dodecyl sulfate (SDS) sample buffer $(10 \mathrm{~mm}$ Tris- $\mathrm{HCl}, 1 \mathrm{~mm}$ EDTA, $2.5 \%$ SDS, $5 \% \beta$-mercaptoethanol, $0.01 \%$ bromophenol blue, $\mathrm{pH}$ 8.0). Both MGAs from unoperated animals were collected in a similar manner and used as controls.

Proteins were fractionated by one-dimensional electrophoresis in polyacrylamide gradient (10-15\%) PhastGels (Pharmacia, LKB, Piscataway, NJ). Gels were silver stained (Heukenshoven and Dernick, 1988) to examine the total protein profile. Silver-stained gels were scanned with a Hoefer GS300 densitometer to determine the apparent molecular weights of various protein bands.

The levels of two specific proteins, actin and $\alpha$-tubulin, were examined on immunoblots of MGA samples from control and experimental crayfish. The proteins were separated on gradient (10-15\%) Phastgels and transferred to Immobilon-P membrane (Millipore, Bedford, MA) using a semidry PhastTransfer kit (Pharmacia). Rainbow markers (Amersham, Arlington Heights, IL) were included to monitor the efficiency of the transfer. The membranes were blocked with 5\% BSA in TBS, rinsed, and incubated with the primary antibody, either mouse monoclonal anti-actin or anti- $\alpha$-tubulin (1:500; Bio-Rad, Richmond, CA), for $1 \mathrm{hr}$. The membranes were rinsed and incubated with secondary antibody, goat anti-mouse IgG conjugated to alkaline phosphatase (1: 3000; Bio-Rad), for $1 \mathrm{hr}$ and developed with an alkaline phosphatase substrate kit (Bio-Rad).

In a blind study, three individuals examined the reactivity to actin and $\alpha$-tubulin on immunoblots of MGA samples from control and experimental crayfish. For each pair of MGAs, the individuals ranked the intensity of the immunoreactive band in one of the MGAs as the same, greater, or less than the intensity of the immunoreactive band in the other MGA. The results were tabulated and a Wilcoxon sign rank test (Sokal and Rohlf, 1992) was used to test for significant differences between intact and anucleate MGAs.

Radiolabeling of axonally transported proteins. Precursor injection, animal sampling, and tissue preparation were performed as previously described (Tanner, 1994). In brief, supraesophageal ganglia of crayfish were injected with either trans ${ }^{35} \mathrm{~S}-\mathrm{met}\left({ }^{35} \mathrm{~S}-\mathrm{met} ; \sim 1000 \mathrm{Ci} / \mathrm{mmol} ; \mathrm{ICN}\right.$ Biochemicals, Irvine, CA) or ${ }^{3} \mathrm{H}$-leucine $\left({ }^{3} \mathrm{H}-\mathrm{leu} ; 170 \mathrm{Ci} / \mathrm{mmol}\right.$; New England Nuclear, Boston, MA) to label proteins during synthesis in the MGA cell bodies. In studies to examine the turnover of fast transported proteins, the right connective of the VNC was severed just caudal to the supraesophageal ganglion $1 \mathrm{~d}$ following the injection of ${ }^{35} \mathrm{~S}-\mathrm{met}$, crayfish were returned to holding tanks $\left(15-18^{\circ} \mathrm{C}\right)$, and anucleate MGAs were sampled up to $28 \mathrm{~d}$ postinjection. The $1 \mathrm{~d}$ postinjection interval was chosen since it permitted the wavefront of radioactively labeled protein in the fast component with an average velocity of $\sim 62 \mathrm{~mm} / \mathrm{d}$ (Tanner et al., 1994) to enter the axon; severance at this time prevented any significant amount of slowly transported protein (at $\sim 0.8 \mathrm{~mm} / \mathrm{d}$ ) from entering the MGA. The turnover of fast transport protein was examined only in anucleate MGAs; similar studies could not be performed in intact MGAs since there was no way to prevent the radiolabeled slow component from entering the axon and contributing to the radiolabel associated with the fast component. [The slow component contains much more radiolabeled protein than the fast component (Tanner et al., 1994).]

The turnover of slowly transported protein was examined in both intact and anucleate MGAs. For these studies, ${ }^{3} \mathrm{H}$-leu (half-life $\approx 12$ yr) was used instead of ${ }^{35} \mathrm{~S}$-met (half-life $\approx 88 \mathrm{~d}$ ) to ensure that the decay time of the radioisotope would not become a significant consideration at the longer postinjection intervals. Crayfish were injected and returned to holding tanks for $14 \mathrm{~d}$ (a sufficient interval for the slow component to enter the axon), at which time one of the connectives was severed immediately caudal to the supraesophageal ganglion. The anucleate and intact MGA from each crayfish were collected 14-56 d postinjection ( $0-49 \mathrm{~d}$ postseverance). Since the radioactivity associated with the slow component is much greater (about 10-fold) than the radioactivity associated with the fast component (Tanner et al., 1994), turnover measurements at these postinjection times were taken to reflect primarily the degradation of slow component proteins.

At the various sampling times, MGA segments $(2.5 \mathrm{~cm})$, beginning just caudal to the supraesophageal ganglion and extending to the first abdominal ganglion, were microdissected from VNCs and homogenized in SDS sample buffer $(17 \mu \mathrm{l})$. In some cases, supraesophageal ganglia were also removed and homogenized ( $68 \mathrm{mg}$ tissue wet weight/ $\mathrm{ml}$ buffer) so that the specific activity in each injected ganglion could be measured by liquid scintillation counting (LSC; see below).

Fluorographic analysis of transported protein. The banding pattern of radiolabeled fast and slow component protein was visualized by fluorography. MGAs from ${ }^{35} \mathrm{~S}$-met-injected crayfish were sampled at $5 \mathrm{hr}$ postinjection (fast component protein) and $21 \mathrm{~d}$ postinjection (slow component protein). After separating the proteins in individual MGA segments $(2.5 \mathrm{~cm})$ by sodium dodecyl sulfate polyacrylamide gel electrophoresis (SDS-PAGE), the gels were infiltrated with EnHance (New England Nuclear), dried, and exposed to x-ray film at $-30^{\circ} \mathrm{C}$ for 3 weeks.

We used fluorography as one of two methods to estimate the half-life of radiolabeled fast transport proteins in anucleate MGAs collected 1$28 \mathrm{~d}$ after injection. At the time of sampling, anucleate MGAs were cut into consecutive $3 \mathrm{~mm}$ segments, the proteins within each segment were separated by SDS-PAGE, and the gels were prepared for fluorography. We found-as have others (Paggi et al., 1989; Lasek et al., 1993)unavoidable variation in the incorporation of radiolabeled amino acids into protein in nerve cell bodies. Thus, to make qualitative comparisons of the radiolabeled proteins in anucleate MGAs sampled at different postinjection times, it was necessary to divide the fluorographs into three groups; each group consisted of fluorographs from experimental animals that had radioactive counts (as measured by LSC) in the supraesophageal ganglia differing by $\leq 20 \%$. The intensities of the radiolabeled protein bands from MGAs within each group were then visually compared. This procedure allowed qualitative comparisons to be made between experimental animals even though there is variability in the incorporation of radiolabeled amino acids into protein by nerve cell bodies in different animals (Paggi et al., 1989; Lasek et al., 1993).

Measurement of radioactivity in proteins. Radioactivity within tissues (MGAs and supraesophageal ganglia) was measured by a trichloracetic acid (TCA) precipitation filter paper method (Mans and Novelli, 1961). Samples of ganglia or MGAs were spotted onto filter paper disks, precipitated in TCA for $1 \mathrm{hr}$, washed with $10 \%$ ethanol, and air dried. Each disk was immersed in $5 \mathrm{ml}$ of 3a70 Complete Counting Cocktail (Dupont, Boston, MA) overnight before counting on a Beckman LSC-1800 counter. This assay provided a measure of acid-insoluble radioactivity (i.e., amino acid incorporated into protein). Values were corrected for background and ${ }^{35} \mathrm{~S}$-met counts were corrected for decay of the isotope (half-life $\approx 88 \mathrm{~d}$ ). All values were expressed as counts per minute $(\mathrm{cpm})$.

Protein degradation was operationally defined as the loss of TCAinsoluble radioactivity over time. The rates of degradation were estimated from the disappearance of radioactivity from axoplasmic proteins. The extent of degradation was expressed in two different ways (see Discussion for evaluation of each method). First, a Model I regression procedure (Sokal and Rohlf, 1992) was used to determine if TCA-insoluble radioactivity decreased as an exponential function of time. Regression line slopes were tested for significance on a semilogarithmic plot using a CRICKETGRAPH program for Macintosh (Computer Associates, San Diego, CA). The average protein half-life (the time required for exponential decay of half of the radioactivity) was determined from the equation of the regression line. Second, the data were plotted as a linear function of time. Using the same program to analyze covariance, a regression line was fitted to the data and a value, the halftime, was determined from the linear decay. The half-time was defined as the time required for the disappearance of half of the radioactivity that was present at the earliest sampling time ( $7 \mathrm{~d}$ for fast component protein and $14 \mathrm{~d}$ for slow component protein). 
Figure 1. Morphological survival of crayfish medial giant axons $(M G A)$. $A$, Cross section of dorsal region of VNC that was severed between the second and third abdominal ganglia at $107 \mathrm{~d}$ prior to sampling. Anucleate MGAs retain a cylindrical shape. $B$, Higher-magnification view of one of the anucleate MGAs showing presence of cytoplasmic organelles. ax, axolemma; ser, smooth endoplasmic reticulum; $m c$, mitochondria; $v s$, vesicle. Scale bars: $A$, $20 \mu \mathrm{m} ; B, 1 \mu \mathrm{m}$.
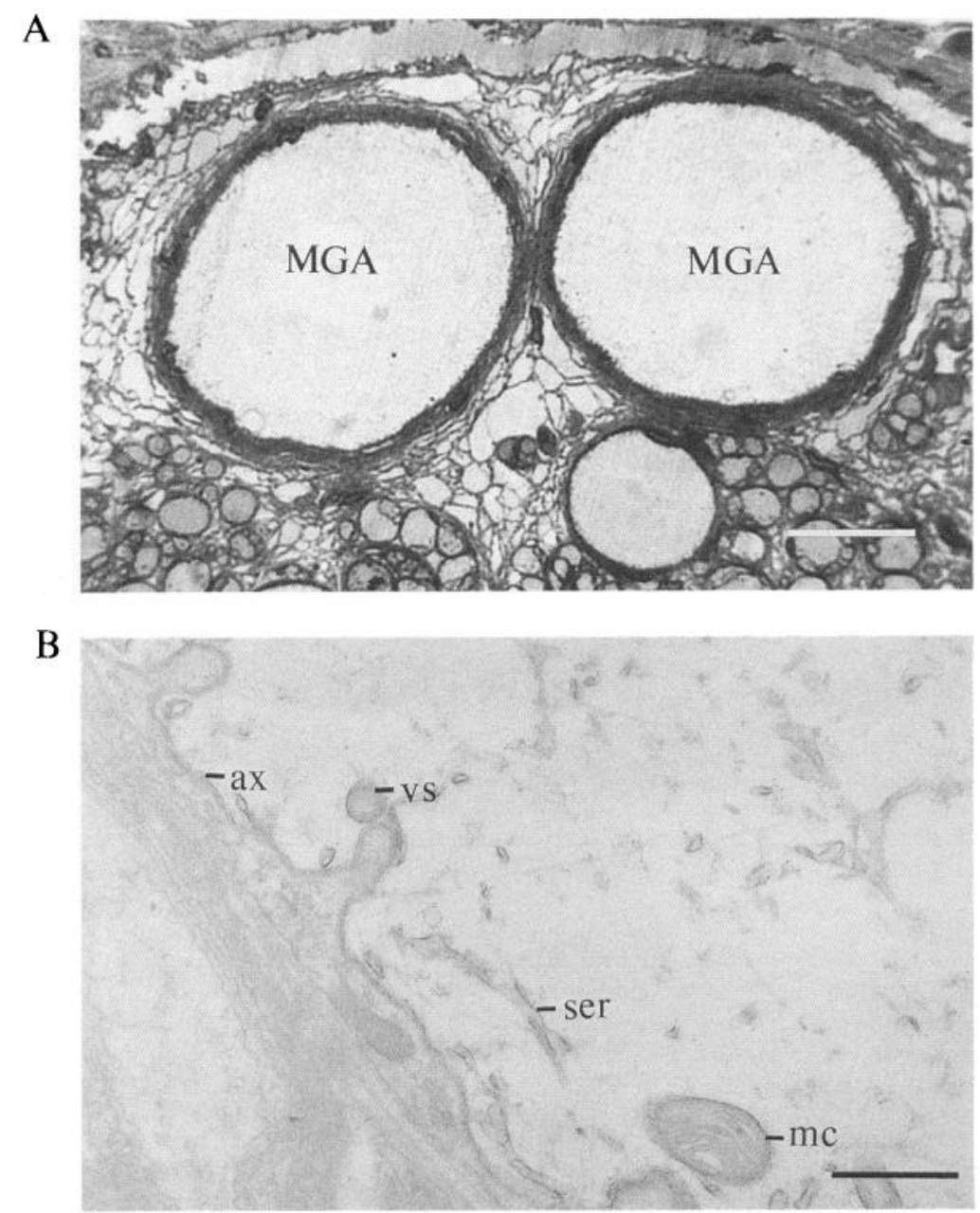

\section{Results}

\section{Morphology of anucleate MGAs}

Anucleate MGA segments severed from their respective cell bodies $(n=5)$ did not exhibit rapid Wallerian degeneration but, rather, remained morphologically intact for months following severance, as previously reported (Wine, 1973; Bittner et al., 1974; Ballinger and Bittner, 1980). Anucleate MGAs exhibited LTS irrespective of whether the severance site was nearer to the cell body (right connective just caudal to the supraesophageal ganglion) or farther from the cell body (between the second and third abdominal ganglia). As illustrated in Figure 1, anucleate MGAs at $107 \mathrm{~d}$ postseverance retained their cylindrical shape, axolemmal integrity, and various cytoplasmic structures (e.g., mitochondria, microtubules, smooth endoplasmic reticulum, vesicles) commonly reported in intact MGAs (Ballinger and Bittner, 1980)-although anucleate MGAs gradually decrease in diameter from 50 to $250 \mathrm{~d}$ postseverance (Wine, 1973; Blundon et al., 1990).

\section{Protein composition in intact versus anucleate MGAs}

Proteins in individual MGAs were separated by gel electrophoresis. The protein banding patterns of the pair of MGAs from control (unoperated) crayfish $(n=10)$ were identical (Fig. 2, 0 mo). Approximately 30 bands were detected on silver-stained gels of intact MGAs; intensely stained bands were at 192,96 , $71,65,59-54,43,28,18$, and $13 \mathrm{kDa}$. Anucleate MGAs severed for $\leq 4$ months $(n=13)$ also had banding patterns very similar to the banding patterns of the paired intact axons (Fig. 2, 2 mo, $4 \mathrm{mo}$ ). These data were consistent with a recent report showing that the proteins in axoperfusates (glia-free axoplasm collected by cannulation) from anucleate MGAs severed for $\leq 6$ months were very similar to the proteins in axoperfusates from intact MGAs (Sheller and Bittner, 1992).

When intact and anucleate MGAs $(n=4)$ were examined at 7 months postseverance, the banding pattern of silver-stained proteins for anucleate MGAs was appreciably different from the banding pattern of the intact axons. Although all protein bands present in intact axons were still detectable, a number of the bands showed decreased staining intensity. For example, bands at 33,55 , and $71 \mathrm{kDa}$ stained less intensely in anucleate MGAs severed for 7 months compared to the paired intact MGAs (Fig. 2, $7 \mathrm{mo}$ ). Many other protein bands in anucleate MGAs severed for 7 months stained with an intensity equal to that observed in the intact axons.

\section{Actin and tubulin in intact versus anucleate MGAs}

The levels of actin (43 kDa) and $\alpha$-tubulin $(55 \mathrm{kDa})$ were examined in pairs of intact MGAs $(n=5)$ from control animals and in paired intact and anucleate MGAs $(n=23)$ from experimental animals in which one of the MGAs had been severed for 1-7 months. The relative amounts of actin and tubulin in the pair of MGAs from each crayfish were estimated from the band intensities on immunoblots (see Materials and Methods). 


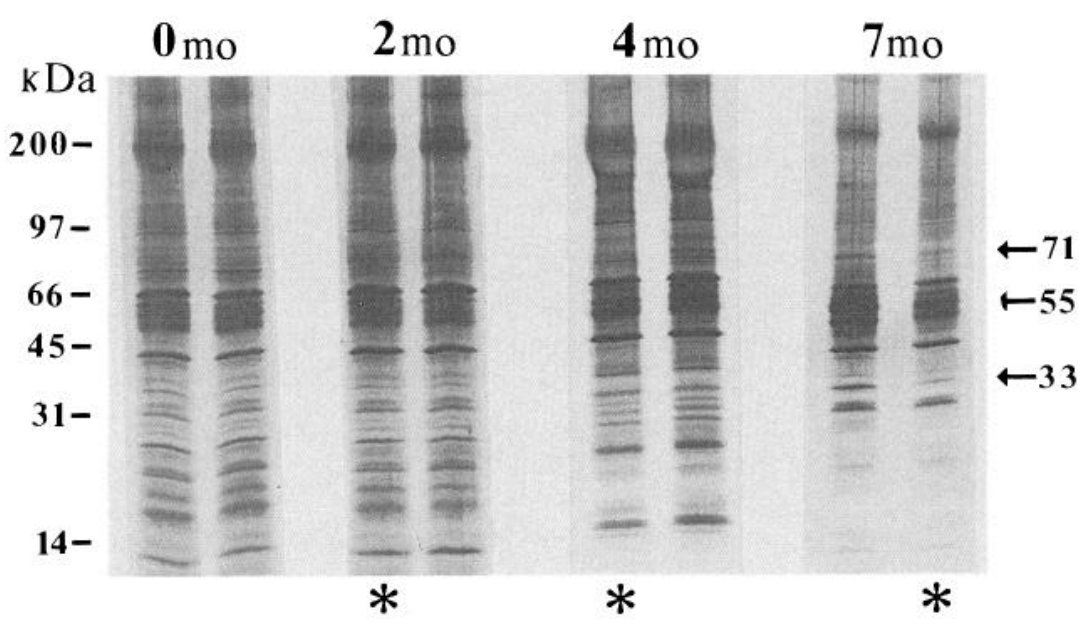

Figure 2. Silver-stained gel of pairs of MGAs from control crayfish $(0 \mathrm{mo})$ and experimental crayfish severed in the right circumesophageal connective for various lengths of time ( $2 \mathrm{mo}, 4 \mathrm{mo}, 7$ $m o$ ). The banding patterns of the pair of MGAs (asterisk indicates the anucleate axon) are the same until 7 months postseverance. At 7 months, the anucleate MGA exhibits a decreased staining intensity of some protein bands (e.g., bands at 33,55 , and $71 \mathrm{kDa}$ labeled with arrows to the right of the figure). Molecular weight markers are indicated by lines to the left of this and subsequent figures.

The level of immunoreactivity to actin or $\alpha$-tubulin was not significantly different $(P>0.05)$ in the pair of MGAs from control animals. There were also no significant differences $(P>$ $0.05)$ in the level of actin immunoreactivity in intact axons compared to anucleate axons $(n=8)$ severed for $\leq 7$ months (Fig. 3A). In contrast to actin immunoreactivity, the level of $\alpha$-tubulin immunoreactivity in anucleate MGAs decreased relative to the tubulin immunoreactivity in the paired intact axons. MGAs severed for $\geq 2$ months $(n=15)$ exhibited less $(P<0.01)$ $\alpha$-tubulin immunoreactivity than that in the intact MGAs (Fig. $3 B)$.

\section{Transported proteins in intact MGAs}

We have recently characterized the fast and slow transport components in MGAs (Tanner et al., 1994). A representative fluorograph of radiolabeled proteins in the transport components is shown in Figure 4. Lane 1 shows proteins in fast transport; the MGA was sampled $5 \mathrm{hr}$ following injection of ${ }^{35} \mathrm{~S}$-met into the supraesophageal ganglion (at this time slowly transported proteins have not yet entered the axon.) Lane 2 shows labeled proteins in an MGA sampled $21 \mathrm{~d}$ following injection; this lane contains some labeled fast component protein not yet degraded as well as slowly transported protein.

\section{Turnover of fast component protein in anucleate MGAs}

The turnover of fast transported proteins in anucleate MGAs was studied by two experimental approaches, one using fluorography and the other LSC of TCA-insoluble radioactivity. For both approaches, fast transport protein was labeled by injection of ${ }^{35} \mathrm{~S}$-met into the supraesophageal ganglion that contains the pair of MGA cell bodies. One MGA from each experimental crayfish was severed from its cell body $1 \mathrm{~d}$ postinjection and radiolabeled protein in the anucleate MGAs was examined 728 d postinjection.

In the first experimental approach, decreases in the intensities of radiolabeled protein bands at progressively later postinjection intervals versus early postinjection times reflected the metabolic degradation of proteins. In these experiments, variation in protein incorporation among animals was controlled by grouping a set of fluorographs according to the specific radioactivity measured in the injected ganglion (see Materials and Methods). Within a grouped set, many of the fast transport proteins in
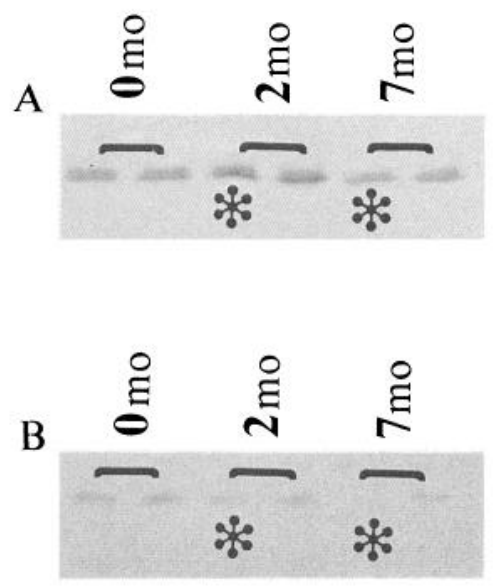

Figure 3. Immunoblots from homogenates of individual anucleate $\left(^{*}\right)$ and paired intact MGAs, probed with anti-actin $(A)$ and anti- $\alpha$-tubulin (B). A, The level of actin in each of the pair of MGAs is the same at all sampling times $(0 \mathrm{mo}, 2 \mathrm{mo}, 7 \mathrm{mo})$. $B$, The level of $\alpha$-tubulin in the anucleate MGA is decreased relative to the amount of $\alpha$-tubulin in the intact axon at 2 months and 7 months after axotomy.

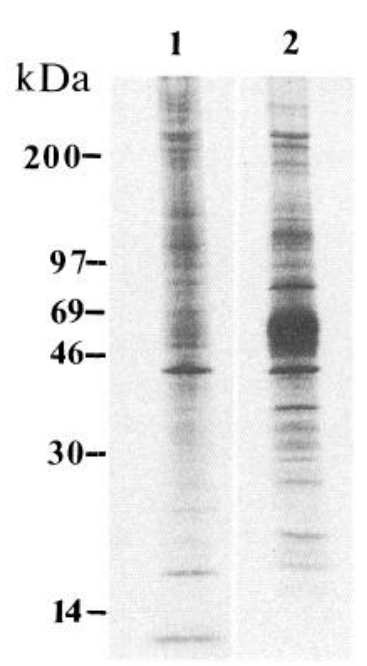

Figure 4. Fluorographic pattern of proteins in fast and slow axonal transport in intact MGAs. The axons were sampled at $5 \mathrm{hr}$ (lane 1) and $21 \mathrm{~d}$ (lane 2) following supraesophageal injection of ${ }^{35} \mathrm{~S}$-met. 


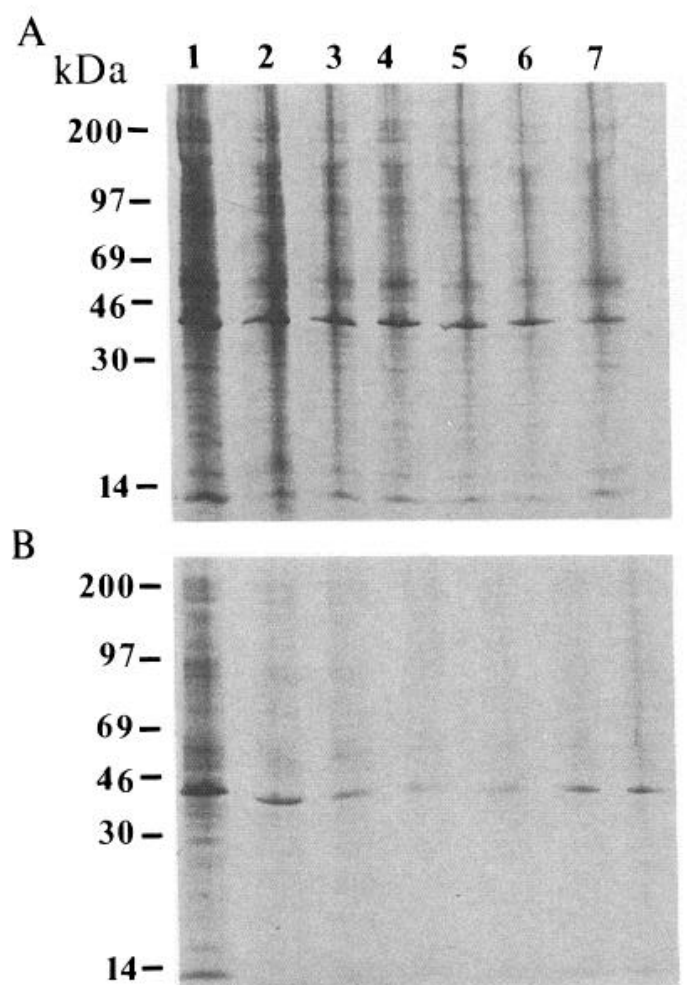

Figure 5. Fluorographs illustrating degradation of fast transport protein in anucleate MGAs. At $7 \mathrm{~d}$ postinjection $(A)$ and $21 \mathrm{~d}$ postinjection $(B)$, the anucleate MGAs (severed $1 \mathrm{~d}$ postinjection) were analyzed by SDS-PAGE/fluorography. Lane 1, most proximal segment; lane 7, most distal segment. The first lane in each figure is most heavily labeled due to local glial incorporation of label, which diffuses into this segment from its injection site in the supraesophageal ganglion 1-2 $\mathrm{mm}$ anterior to lane 1 (Tanner, 1994). Note the decrease in radiolabeled proteins in all lanes at $21 \mathrm{~d}$ compared to $7 \mathrm{~d}$ postinjection.

anucleate MGAs collected at later postinjection times were less intensely labeled on fluorographs compared to those protein bands from MGAs collected at early postinjection intervals. For example, as illustrated in Figure 5, most of the fast component proteins in the MGA sampled at $21 \mathrm{~d}$ postinjection (Fig. 5B) were less intensely labeled than those in the MGA sampled at $7 \mathrm{~d}$ postinjection (Fig. $5 \mathrm{~A}$ ). By $21 \mathrm{~d}$, most of the labeled protein bands were only faintly detectable (one exception being the 43 $\mathrm{kDa}$ band, which was still strongly labeled $21 \mathrm{~d}$ postinjection). The decreased intensities of labeled bands in MGAs examined at $21 \mathrm{~d}$ postinjection compared to the bands in MGAs analyzed at $7 \mathrm{~d}$ postinjection suggest that many proteins in the fast component of axonal transport were degraded within this $14 \mathrm{~d}$ interval.

In the second experimental approach, the rate of protein degradation was estimated by measuring the disappearance of TCAinsoluble radioactivity. Anucleate MGAs were sampled at various postseverance times and the half-life of the radioactivity in the axons was determined by LSC and plotted against time (Fig. 6). When expressed as an exponential function of time, the TCA-insoluble radioactivity in MGAs decreased over the $28 \mathrm{~d}$ postinjection interval with a slope that was significantly different from zero at $P<0.01$ (Fig. 6A). The average half-life (time for loss of half the radiolabel) of the fast component proteins was $14 \mathrm{~d}$ as calculated from the equation of the regression line: $y=$ $3627.9 \cdot 10^{-0.02175 x}$

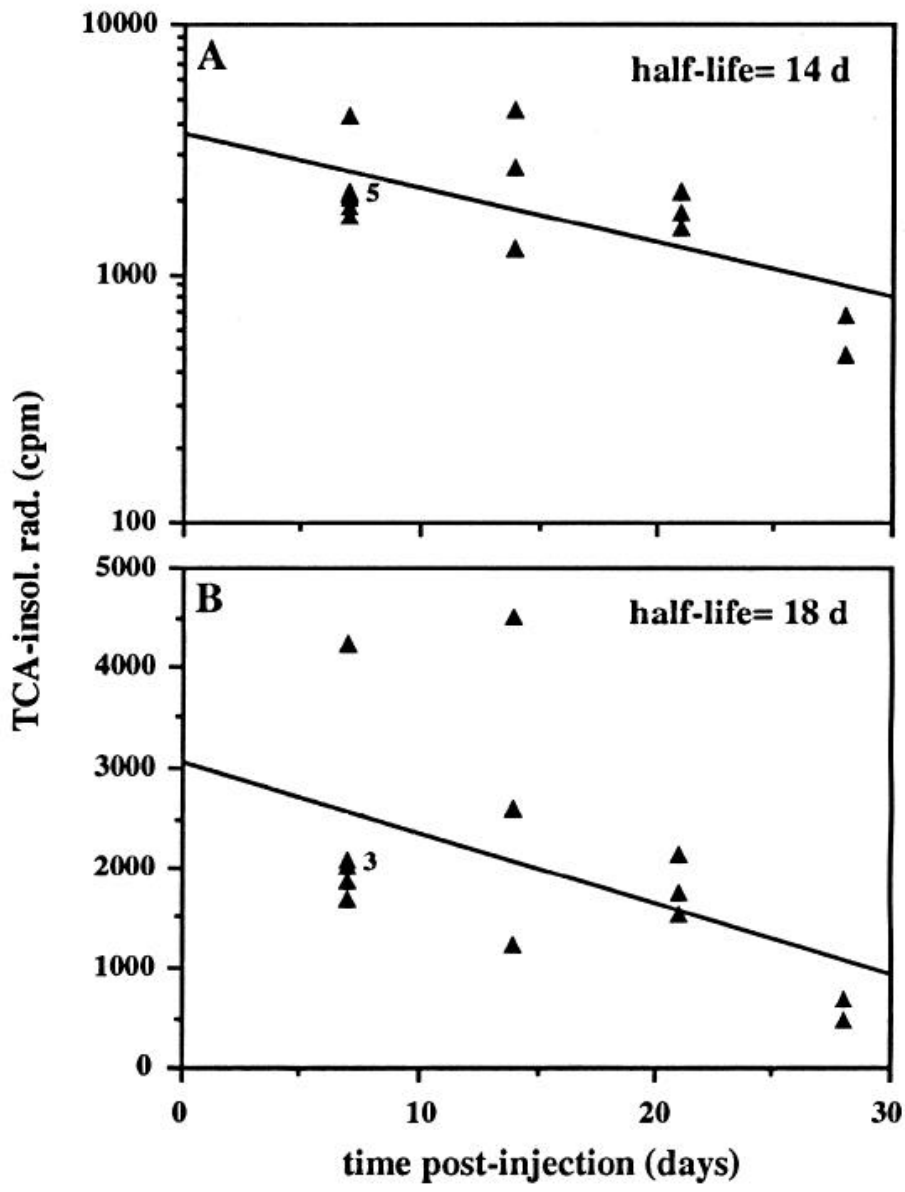

Figure 6. Disappearance of radioactivity associated with fast component protein in anucleate MGAs. Each data point on the graph represents a single anucleate MGA (severed at $1 \mathrm{~d}$ postinjection), except for those points with numbers to the right, which indicate the number of axons that share a similar measurement of radioactivity. In $A$ the TCA-insoluble radioactivity (i.e., radioactivity associated with protein) is expressed as an exponential function of time postinjection. Solid line, regression of radioactivity versus postinjection time drawn according to the equation $y=3627.9 \cdot 10^{-0.02175 . x}, r^{2}=0.434, n=14, P<0.01$. From these data, the half-life of fast component protein is about $14 \mathrm{~d}$. In $B$ the TCA-insoluble radioactivity is plotted as a linear function of time. Solid line, regression of radioactivity versus postinjection time drawn according to the equation $y=3059.2-70.039 x, r^{2}=0.246, n$ $=14, P<0.05$. The half-time of fast component protein is about $18 \mathrm{~d}$.

Although the loss of labeled amino acids from an individual protein that occurs as a result of degradation is usually assumed to be exponential (Doherty and Mayer, 1992), there are several reasons why this assumption may not be entirely appropriate for describing degradation of a heterogeneous group of transported proteins in intact or in anucleate axons (see Discussion). Thus, we also expressed the loss of radioactivity as a linear function of time. As shown in Figure $6 B$, there was a significant decrease over time in the TCA-insoluble radioactivity $(P<$ $0.05)$. The equation of the regression line describing this relationship was $y=3059.2-70.039 x$. The half-time of the radioactivity associated with the fast component was defined as the time required for the loss of half of the radioactivity initially present at $7 \mathrm{~d}$ postinjection. With a linear disappearance of radioactivity, the half-time for loss of fast component protein was $18 \mathrm{~d}$. 

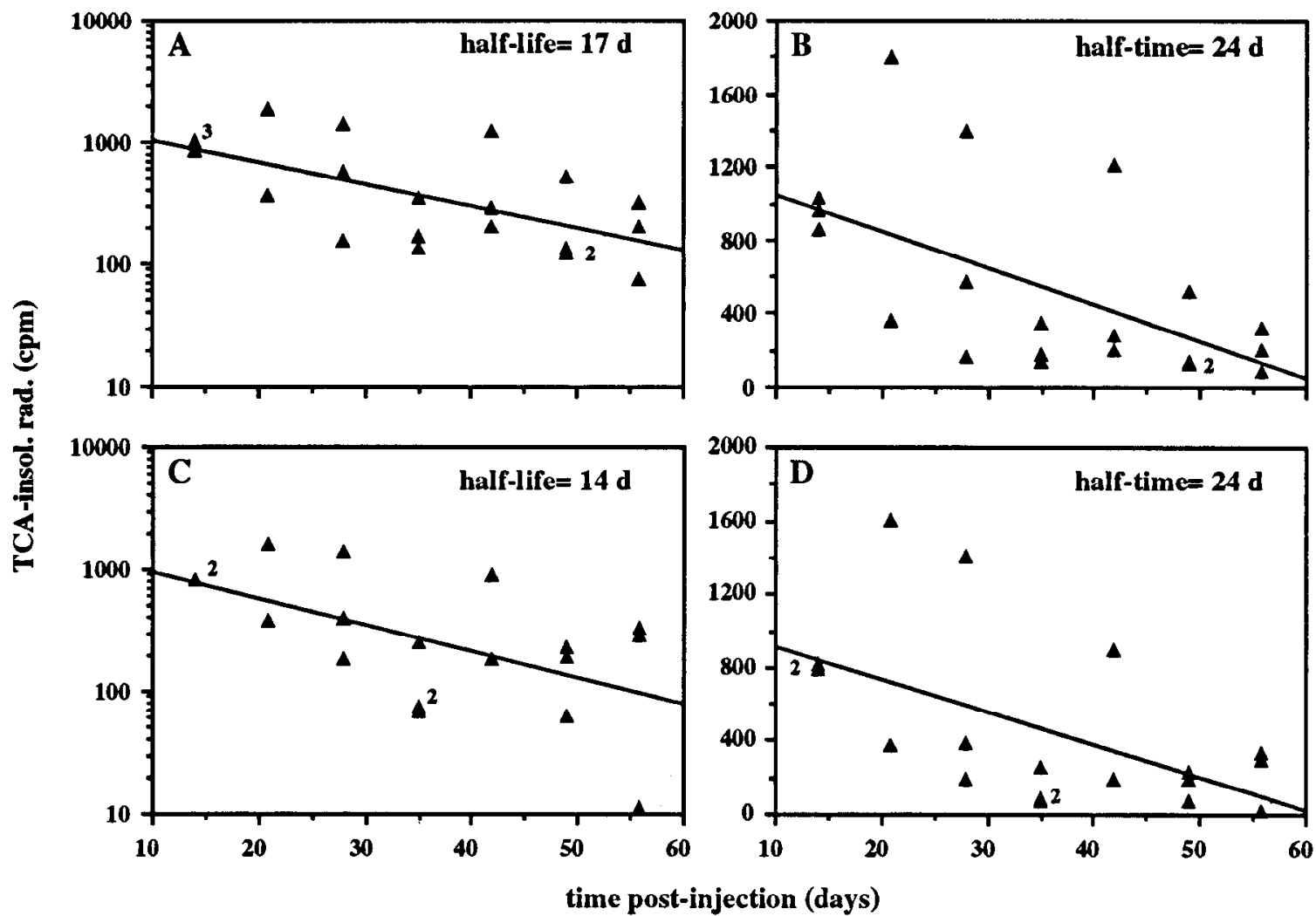

Figure 7. Disappearance of radioactivity associated with slow component protein in anucleate $(A, B)$ and contralateral intact MGAs $(C, D)$. The right VNC connectives were severed $14 \mathrm{~d}$ following supraesophageal injection of ${ }^{3} \mathrm{H}$-leu. At the indicated intervals, both the intact (left) and anucleate (right) MGAs were microdissected from the VNCs and assayed for radioactivity. In $A$ the TCA-insoluble radioactivity in anucleate MGAs is expressed as an exponential function of time. Solid line, regression of radioactivity versus postinjection time drawn according to the equation $y$ $=1548.1 \cdot 10^{-0.01791 . x}, r^{2}=0.392, n=20, P<0.01$. From these data, the average half-life of slowly transported protein in anucleate MGAs is about $17 \mathrm{~d}$. In $B$ the TCA-insoluble radioactivity is plotted as a linear function of time. Solid line, regression of radioactivity versus time drawn according to the equation $y=1241.1-19.757 x, r^{2}=0.325, n=20, P<0.01$. The half-time for slowly transported protein is about $24 \mathrm{~d}$. $C$, The TCA-insoluble radioactivity in the intact MGAs is expressed as an exponential function of time with a regression line $y=1575.9 \cdot 10^{-0.02172 x}, r^{2}$ $=0.322, n=18, P<0.01$. The average half-life is about $14 \mathrm{~d}$ for slowly transported protein in intact MGAs. $D$, The TCA-insoluble radioactivity is expressed as a linear function of time with the regression line $y=1097.4-17.776 x, r^{2}=0.295, n=18, P<0.02$. The half-time of the slow component radiolabeled protein is about $24 \mathrm{~d}$.

\section{Turnover of slow component protein in anucleate MGAS}

The turnover of slowly transported protein in anucleate MGAs was examined over an interval of 14-56 d following supraesophageal ganglionic injection of ${ }^{3} \mathrm{H}$-leu. For these experiments, MGAs of injected crayfish were severed at $14 \mathrm{~d}$ postinjection, which was sufficient time for the front of slowly transported protein to enter the axon prior to axotomy. At the various sampling times, MGAs were dissected, homogenized, and prepared for LSC. The TCA-insoluble radioactivity associated with the slow component was plotted in the two ways described for the analysis of fast component proteins. The TCAinsoluble radioactivity associated with ${ }^{3} \mathrm{H}$-labeled proteins in the slow component were lower than the TCA-insoluble radioactivity associated with ${ }^{35} \mathrm{~S}$-labeled proteins in the fast component, probably because the ${ }^{3} \mathrm{H}$-leu we used to label slow component protein had a much lower specific activity $(\sim 170 \mathrm{Ci}$ / mmol compared to $\sim 1000 \mathrm{Ci} / \mathrm{mmol}$ for ${ }^{3} \mathrm{~S}$-met). As shown in Figure $7 A$, there was a significant $(P<0.01)$ decrease in the amount of radioactivity in anucleate MGAs sampled between 14 and $56 \mathrm{~d}$ postinjection when the loss of TCA-insoluble radioactivity was expressed as an exponential function of time. The average half-life of slow component protein was $17 \mathrm{~d}$ as calculated from the equation of the regression line: $y=1548$ * $10^{-0.01791 x}$.

In Figure $7 B$, the disappearance of TCA-insoluble radioactivity is shown as a linear function of time $(P<0.01)$. The equation of the regression line that describes this relationship was $y=1241.1-19.757 x$. From this equation, the half-time of loss of slow component protein was $24 \mathrm{~d}$.

\section{Turnover of slow component protein in intact $M G A S$}

The turnover of slow component protein was also examined in intact MGAs. When the TCA-insoluble radioactivity was plotted on a logarithmic scale (Fig. $7 C$ ), there was a significant $(P$ $<0.01)$ loss of labeled protein. From the equation $y=1575.9$ $* 10^{-0.02172 x}$, an average half-life of $14 \mathrm{~d}$ was calculated for slow component protein. The half-life of slow component protein in intact MGAs was not significantly different $(P>0.05)$ than the half-life $(17 \mathrm{~d})$ calculated for slow component proteins in anucleate MGAs.

When expressed as a linear function of time (Fig. $7 D$ ), the equation describing the loss of labeled protein was $y=1097.4$ $-17.776 x(P<0.02)$. The half-time for the luss of slowly transported protein in intact MGAs was $24 \mathrm{~d}$, which was the 
same half-time observed for slow component protein in anucleate MGAs.

\section{Discussion}

Viability and protein maintenance in anucleate $M G A s$

A number of histological and physiological studies have shown that the crayfish MGA remains intact and functionally competent for many months after separation from its cell body (reviewed in Bittner, 1981, 1988, 1991). An anucleate MGA retains the cylindrical shape, intact axolemma, and cytoplasmic organelles (including microtubules) commonly observed in an intact MGA. Although anucleate MGAs remain viable, some changes do occur in these axons following severance. For example, the glial sheath surrounding the MGA undergoes extensive hypertrophy and hyperplasia for weeks following severance (Bittner et al., 1974; Meyer and Bittner, 1978; Ballinger and Bittner, 1980). The diameter of anucleate MGAs decreases gradually beginning about $50 \mathrm{~d}$ after axotomy (Wine, 1973) and does not completely collapse until 200-250 d after axotomy (Bittner et al., 1974; Bittner, 1981, 1991; Blundon et al., 1990). Vesicle motility associated with fast axonal transport virtually ceases within 3-4 weeks after severance (Viancour, 1990; Tanner et al., 1994), even though anucleate MGAs contain many microtubules (Fig. 1; Ballinger and Bittner, 1980; Tanner et al., 1994). Our present data indicate that all protein species detected in intact MGAs are also detected in anucleate MGAs severed for as long as 7 months. Furthermore, many of the proteins in 7 month anucleate MGAs are maintained at a level similar to that in intact MGAs.

In principle, there are two mechanisms that could account for protein maintenance in anucleate MGAs: slow protein turnover and/or axonal uptake of newly synthesized protein. These two mechanisms differ significantly in the source of axoplasmic proteins. If the only source of axoplasmic proteins is via transport from the neuronal cell body, then proteins in anucleate MGAs that exhibit LTS must remain metabolically stable for many months. Alternatively, the perikaryal supply of protein might be supplemented by local synthesis; for example, proteins synthesized in adaxonal glia could be transferred to the MGA. The primary objective of this study was to determine if slow degradation of axonally transported protein in anucleate MGAs could account for LTS. A second objective was to examine the average rate of protein degradation in intact axons since these data have important implications for mechanisms of protein maintenance under normal physiological conditions.

\section{Turnover of transported protein in intact MGAs and other axons}

Although the degradation of any given cellular protein is usually assumed to be a first-order process, there are several reasons why the average rate of degradation for a set of axonally transported proteins might not be a first-order process. First, the definition of the average rate of degradation presents certain methodological problems since individual cellular proteins turn over at very different rates. Thus, in a pulse-chase experiment, the average loss of label from a heterogeneous group of proteins may not follow exponential decay kinetics, even if each individual species of protein exhibits exponential decay (Goldberg and Dice, 1970). Second, exponential loss of radiolabel from protein implies that protein degradation is random (Doherty and Mayer, 1992); that is, a newly synthesized protein is just as likely to be degraded as a protein that has been synthesized for some time. This assumption may not hold for transported protein. For example, fast component proteins are known to be conveyed in vesicles that could serve to protect proteins from degradative processes. Finally, it is conceivable that the rate of protein degradation in axons may be limited by low proteolytic activity, perhaps resulting from limited axonal transport of proteases or from local protease inhibition. Anucleate axons might be particularly deficient in proteases if such enzymes are normally supplied by the cell body and have a short half-life. Since the rate of degradation of transported proteins may not be a first-order process, we have also expressed the rate as a zeroorder process, in which case the radioactivity would decrease as a linear function of time.

In MGAs (Tanner et al., 1994) and other axons (Grafstein and Forman, 1980) the bulk of labeled transported protein is conveyed in the slow component, a large proportion of which is deposited in proximal axonal segments as the slow wave moves down the fibers (Schonbach et al., 1973; Cancalon, 1979, 1982). It is not known whether these transported proteins turn over at rates similar to other cellular proteins or whether they are in some way modified and protected from degradation. In addition to cytoskeletal elements, the slow component contains many of the glycolytic enzymes such as enolase, creatine phosphokinase, aldolase, pyruvate kinase, and lactic dehydrogenase (Brady and Lasek, 1981, 1982). Similar "housekeeping" enzymes in non-neuronal cells exhibit half-lives in the order of hours (Goldberg and St. John, 1970; Doherty and Mayer, 1992). In long axons in particular, it would seem necessary that these proteins in the slow component must somehow be protected from proteolysis while in transit since they may take months to arrive at the distal portion of a long axon. Unlcss modified in route, virtually none of the enzymes in the slow component would be left for maintenance of the distal region of a long axon.

Most studies on turnover of transported protein have been conducted on axons and terminals in vertebrate visual systems. For example, the radioactivity associated with fast and slow components declines nearly linearly with a half-time of $\sim 6$ weeks in the goldfish optic system (Grafstein et al., 1972). Slow component proteins in rabbit ganglion cells have a half-life of $14 \mathrm{~d}$ (Karlsson and Sjostrand, 1971). Half-lives of $14 \mathrm{~d}$ (Grafstein et al., 1972) and 2-7 d (Nixon, 1980) are exhibited by slowly transported proteins in terminals of mouse retinal ganglion cell neurons. The half-residence times of neurofilament protein, actin, and tubulin in oculomotor synapses are 2, 3.5, and $7 \mathrm{~d}$, respectively (Paggi and Lasek, 1987). Transported neurofilament proteins exhibit two exponential rates of decay, with halflives of 20 and $55 \mathrm{~d}$ (Nixon and Logvinenko, 1986). Finally, at least one isoform of transported tubulin appears to persist as long as $400 \mathrm{~d}$ in guinea pig CNS nerve terminals (Garner, 1988).

In our study, the measured rate of degradation of slow component protein in intact MGAs (half-life of $14 \mathrm{~d}$, half-time of 24 d) seems unduly short for proteins that may travel for many weeks or months to reach their final destination. For example, protcins in the slow component $(0.8 \mathrm{~mm} / \mathrm{d}) \mathrm{nccd}$ to travel up to $50 \mathrm{~d}$ to reach the end of a $40 \mathrm{~mm}$ MGA [average length of MGAs from juvenile crayfish used in this study; large adult crayfish have even longer MGAs ( $\geq 140 \mathrm{~mm}$ ) with travel times of $\geq 160 \mathrm{~d}$ ]. Assuming a half-life of $14 \mathrm{~d}$, somewhat more than $88 \%$ of the protein would be degraded in route before ever reaching the end of a $40 \mathrm{~mm}$ MGA; a much greater percentage would be degraded before reaching the end of a $140 \mathrm{~mm}$ MGA. These results suggest that intact MGAs may have a secondary 
source to supplement proteins normally supplied by the cell body in slow transport.

\section{Turnover of transported protein in anucleate MGAs}

By severing MGAs $1 \mathrm{~d}$ following exposure of the cell bodies to radiolabeled precursors, we selectively examined the turnover of fast transport protein deposited in the axons. The radiolabel associated with fast component proteins obviously decreased on fluorographs of MGAs sampled at progressively later postinjection times. These qualitative observations were quantitatively confirmed by measuring TCA-insoluble radioactivity in anucleate MGAs at various postinjection intervals. Whether expressed as an exponential loss (half-life of $14 \mathrm{~d}$ ) or as a linear decay (half-time of $18 \mathrm{~d}$ ), the measured rate of degradation of fast component protein seems very unlikely to account for the survival of anucleate MGAs.

Protein half-lives in anucleate MGAs might be much longer than protein half-lives in intact MGAs (Sheller and Bittner, 1992). Enucleation of mammalian cells has been reported to increase protein lifespan (Gopalakrishman and Thompson, 1977; Cavenee et al., 1981). However, we found that the average halflife of slow component protein in anucleate MGAs $(17 \mathrm{~d})$ was not significantly different than the half-life measured in intact MGAs (14 d), nor were there any differences in the degradation rates when expressed as a half-time. These data suggest that axotomy has little net effect on the rate of protein degradation in MGAs.

The measured rate of turnover of slow component protein (half-life of $17 \mathrm{~d}$, half-time of $24 \mathrm{~d}$ ) is unlikely to account for the ability of an anucleate MGA to survive for over 7 months following separation from its cell body. Thesc data suggest that anucleate MGAs have a secondary source to supplement proteins synthesized by the cell body.

It is possible that our estimates of the apparent half-life of transported protein in the axoplasm of intact or anucleate MGAs are affected by the degradation of transported proteins whose radiolabeled amino acids are then reincorporated into proteins by local glial cells. This possibility would cause us to overestimate the true half-life (or half-time) of transported proteins in the fast or slow component. However, reincorporation by glial cells may be a rather small artifact, since we detected no qualitative differences in the radiolabeled banding pattern over time in anucleate MGAs. It is also quite likely that different axoplasmic proteins have different half-lives. (Our LSC counts provided data only for the average half-life of all axoplasmic protein.) For example, compared to intact MGAs, the axoplasmic levels of tubulin-but not actin-obviously decrease in anucleate MGAs at 7 months after axotomy (Fig. 2). Relative to actin, the decreased level of tubulin in 7 month anucleate MGAs could result from a more rapid degradation of axonal tubulin or a lesser capacity for glial synthesis and transfer of tubulin to the MGA. In fact, much actin-but very little, if any, tubulinappears to be transferred from glia to an adjacent MGA (Tanner et al., 1992; R. A. Sheller, personal communication).

\section{Alternative source of axoplasmic protein}

Although glial cells have long been known to provide "trophic support" that is vital to the maintenance of normal neuronal structure and function, the nature and extent of this support have been elusive. Some data from both mammalian and invertebrate preparations are consistent with the hypothesis that glia may contribute to the protein maintenance of axons. In mammals, glial cells transfer $\beta$-galactosidase to embryonic neurons that traverse the ventral floor plate of the spinal cord (Campbell and Peterson, 1993). Astrocytes located near nodes of Ranvier may function as subsidiary sites for the synthesis of sodium channels that are transferred to the axon (Gray and Ritchie, 1985; Shrager et al., 1985; Black and Waxman, 1988; England et al., 1990; Waxman and Ritchie, 1993). Differentiating Schwann cells in the immature sciatic nerve synthesize one subunit (NF-M) of neurofilament proteins (Kelly et al., 1992) that are generally regarded as specific to neurons. Certain neurotrophic factors (e.g., ciliary neurotrophic factor) synthesized by Schwann cells are retrogradely transported in axons and can retard axonal degeneration (Masu et al., 1993).

Compared to data from mammals cited above, glia-to-axon protein transfer has becn more convincingly characterized in two invertebrate preparations, the squid giant axon (Lasek et al., 1974, 1977; Gainer et al., 1977; Lasek and Tytell, 1981; Tytell and Lasek, 1984; Tytell et al., 1986) and the crayfish MGA (Bittner, 1977; Meyer and Bittner, 1978; Sheller and Bittner, 1992). In squid and in crayfish axons, a large, heterogeneous group of proteins synthesized by glial cells are transferred to the axon. The present study on degradation of transported protein in MGAs suggests that the normal cell body supply of proteins may not completely support an intact MGA and almost certainly cannot entirely support an anucleate MGA. Our data are consistent with previous observations that proteins are transferred from glia to intact and anucleate MGAs (Meyer and Bittner, 1978; Sheller and Bittner, 1992) and with the hypothesis that the transferred glial proteins are critical to maintaining axonal viability during LTS of anucleate MGAs. Glia-to-axon protein transfer may also contribute to the maintenance of intact or anucleate axonal processes in other nervous systems.

\section{References}

Ballinger M, Bittner GD (1980) Ultrastructural studies of severed medial giant and other CNS axons in crayfish. Cell Tissue Res 208: 123-133.

Birse SC, Bittner GD (1976) Regeneration of giant axon in earthworms. Brain Res 113:575-581.

Bittner GD (1973) Degeneration and regeneration in crustacean neuromuscular systems. Am Zool 13:379-408.

Bittner GD (1977) Trophic interactions of crustacean neurons. In: Identified neurons and behavior of arthropods (Hoyle G, ed), pp 507532. New York: Plenum.

Bittner GD (1981) Trophic interactions of CNS giant axons in crayfish. Comp Biochem Physiol 68A:299-306.

Bittner GD (1988) Long tcrm survival of severed distal axonal stumps in vertebrates and invertebrates. Am Zool 28:1165-1179.

Bittner GD (1991) Long-term survival of anucleate axons and its implications for nerve regeneration. Trends Neurosci 14:188-193.

Bittner GD, Ballinger ML, Larimer JL (1974) Crayfish central nervous system: minimal degenerative-regenerative changes after lesioning. $J$ Exp Zool 189:13-36.

Black JA, Waxman SG (1988) The perinodal astrocyte. Glia 1:169183.

Blundon JA, Sheller RA, Moehlenbruck JW, Bittner GD (1990) Effects of temperature on long term survival of anucleate giant axons in crayfish and goldfish. J Comp Neurol 297:377-391.

Brady ST, Lasek RJ (1981) Nerve-specific enolase and creatine phosphokinase in axonal transport: soluble proteins and the axoplasmic matrix. Cell 23:515-523.

Brady ST, Lasek RJ (1982) The slow components of axonal transport: movements, composition and organization. In: Axoplasmic transport (Weiss DG, ed), pp 206-217. Berlin: Springer.

Campbell RM, Peterson AC (1993) Expression of a lac2 transgene reveals floor plate morphology and macromolecular transfer to commissural axons. Development 119:1217-1228.

Cancalon P (1979) Influence of temperature on the velocity and on 
the isotope profile of slowly transported labeled proteins. J Neurochem 32:997-1007.

Cancalon $P$ (1982) Slow flow in axons detached from their perikarya. J Cell Biol 95:989-992.

Cancalon P (1983) Proximodistal degeneration of C-fibers detached from their perikarya. J Cell Biol 97:6-14.

Cavenee WK, Chen HW, Kandutsch AA (1981) Regulation of cholesterol biosynthesis in enucleated cells. J Biol Chem 256:2675-2681.

Clark RD (1976) Structural and functional changes in an identified cricket neuron after separation from the soma. I. Structural changes. J Comp Neurol 170:253-266.

Doherty FJ, Mayer RJ (1992) Intracellular protein degradation. New York: Oxford UP.

England JD, Gamboni F, Levinson SR, Finger TE (1990) Changed distribution of sodium channels along emyelinated axons. Proc Natl Acad Sci USA 87:6777-6780.

Gainer H, Tasaki I, Lasek RJ (1977) Evidence for the glia-neuron protein transfer hypothesis from intracellular perfusion studies of squid giant axons. J Cell Biol 74:524-530.

Garner JA (1988) Differential turnover of tubulin and neurofilament proteins in central nervous system neuron terminals. Brain Res 458: 309-318.

Goldberg AL, Dice JF (1970) On the measurement of protein turnover in animal cells. J Biol Chem 247:5234-5242.

Goldberg A, St. John AC (1970) Intracellular protein degradation in mammalian and bacterial cells: part II. Annu Rev Biochem 45:747803.

Gopalakrishman TV, Thompson EB (1977) The stability of tyrosine aminotransferase and other proteins in enucleated rat hepatoma tissue culture cells. J Cell Physiol 93:69-80.

Grafstein B, Forman DS (1980) Intracellular transport in neurons. Physiol Rev 60:1167-1283.

Grafstein B, Forman DS, McEwen BS (1972) Effects of temperature on axonal transport and turnover of protein in goldfish optic system. Exp Neurol 34:158-170.

Gray PT, Ritchie JM (1985) Ion channels in Schwann and glial cells. Trends Neurosci 8:411-415.

Heukenshoven J, Dernick R (1988) Improved silver staining procedure for fast staining in PhastSystem Development Unit I. Staining of sodium dodecyl sulfate gels. Electrophoresis 9:28-32.

Hoy RR, Bittner GD, Kennedy D (1967) Regeneration in crustacean motorneurons: evidence for axonal fusion. Science 156:251-252.

Karlsson J-O, Sjostrand J (1971) Synthesis: migration and turnover of protein in retinal ganglion cells. J Neurochem 18:749-761.

Kelly BM, Gillespie CS, Sherman DL, Brophy PJ (1992) Schwann cells of the myelin-forming phenotype express neurofilament protein NF-M. J Cell Biol 118:397-410.

Lasek RJ, Tytell M (1981) Macromolecular transfer from glia to the axon. J Exp Biol 95:153-165.

Lasek RJ, Gainer H, Przylbylski RJ (1974) Transfer of newly synthesized proteins from Schwann cells to the squid giant axon. Proc Natl Acad Sci USA 71:1188-1192.

Lasek RJ, Gainer H, Barker JL (1977) Cell-to-cell transfer of glial proteins to the squid giant axon. J Cell Biol 74:501-523.

Lasek RJ, Paggi P, Katz M (1993) The maximum rate of neurofilament transport in axons: a view of molecular transport mechanisms continuously engaged. Brain Res 616:58-64.

Lunn ER, Perry VH, Brown MC, Rosen H, Gordon S (1989) Absence of Wallerian degeneration does not hinder regeneration in peripheral nerve. Eur J Neurosci 1:27-33.

Mans RJ, Novelli GD (1961) Measurement of the incorporation of radioactive amino acid into protein by a filter-paper disc method. Arch Biochem Biophys 94:48-53.
Masu Y, Wolf E, Holtmann B, Sendtner M, Brem G, Thoenen H (1993) Disruption of the CNTF gene results in motor neuron degeneration. Nature 365:27-31.

Matsumoto DE, Scalia F (1981) Long-term survival of centrally projecting axons in the optic nerve of the frog following destruction of the retina. J Comp Neurol 202:135-155.

Meyer MR, Bittner GD (1978) Histological studies of the trophic dependencies in crayfish giant axons. Brain Res 143:195-211.

Muller KJ, Carbonetto S (1979) The morphological and physiological properties of a regenerating synapse in the CNS of the leech. J Comp Neurol 185:485-516.

Murphy AD, Kater SB (1978) Specific reinnervation of a target organ by a pair of identified molluscan neurons. Brain Res 156:322-328.

Nixon RA (1980) Protein degradation in the mouse visual system I. Degradation of axonally transported and retinal proteins. Brain Res 200:69-83.

Nixon RA, Logvinenko KB (1986) Multiple fates of newly synthesized neurofilament proteins: evidence for a stationary neurofilament network of retinal ganglion cell neurons. J Cell Biol 102:647-659.

Ochs S (1989) Developments in neurochemistry related to axoplasmic transport. Neurochem Int 14:289-298.

Paggi P, Lasek RJ (1987) Axonal transport of cytoskeletal protein in oculomotor axons and their residence times in axonal terminals. $\mathrm{J}$ Neurosci 7:2391-2411.

Paggi P, Lasek RJ, Katz MJ (1989) Slow component protein kinetics in optic nerve and tract window. Brain Res 504:223-230.

Peters A, Palay SL, Webster HF (1991) The fine structure of the nervous system: the neurons and supporting cells, 3d ed. New York: Oxford UP.

Schonbach J, Schonbach CH, Cuenod M (1973) Distribution of transported proteins in the slow phase of axoplasmic flow: an electron microscopical autoradiographic study. J Comp Neurol 152:1-16.

Sheller RA, Bittner GD (1992) Maintenance and synthesis of proteins for an anucleate axon. Brain Res 580:68-80.

Shrager P, Chiu SY, Ritchie JM (1985) Voltage-dependent sodium and potassium channels in mammalian cultured Schwann cells. Proc Natl Acad Sci USA 82:948-952.

Sokal RR, Rohlf FJ (1992) In: Biometry (Freeman WH, ed), p 859. New York: Freeman.

Tanner SL (1994) Protein transport and turnover in crayfish medial giant axons. PhD thesis, University of Texas in Austin.

Tanner SL, Storm EE, Sheller RA, Bittner GD (1992) Protein maintenance in axotomized crayfish medial giant axons. Soc Neurosci Abstr 18:67.

Tanner SL, Storm EE, Bittner GD (1994) Protein transport in intact and severed (anucleate) crayfish giant axons. J Neurochem, in press.

Tytell M, Lasek RJ (1984) Glial polypeptides transferred into the squid axon. Brain Res 324:223-232.

Tytell M, Greenberg SG, Lasek RJ (1986) Heat shock-like protein is transferred from glia to axon. Brain Res 363:161-164.

Van Harreveld A (1936) A physiological solution for fresh water crustaccans. Proc Soc Exp Biol Med 34:428-432.

Viancour TA (1990) Organelle flux in intact and transected crayfish giant axons. Brain Res 535:245-254.

Waxman SG, Ritchie JM (1993) Molecular dissection of the myelinated axon. Ann Neurol 33:121-136.

Wine JJ (1973) Invertebrate central neurons: orthograde degeneration and retrograde changes after axotomy. Exp Neurol 38:157-169.

Zottoli SJ, Marek LE, Agostini MA (1986) Morphological and physiological survival of goldfish Mauthner axons isolated from their somata by spinal cord crush. J Comp Neurol 230:497-516. 